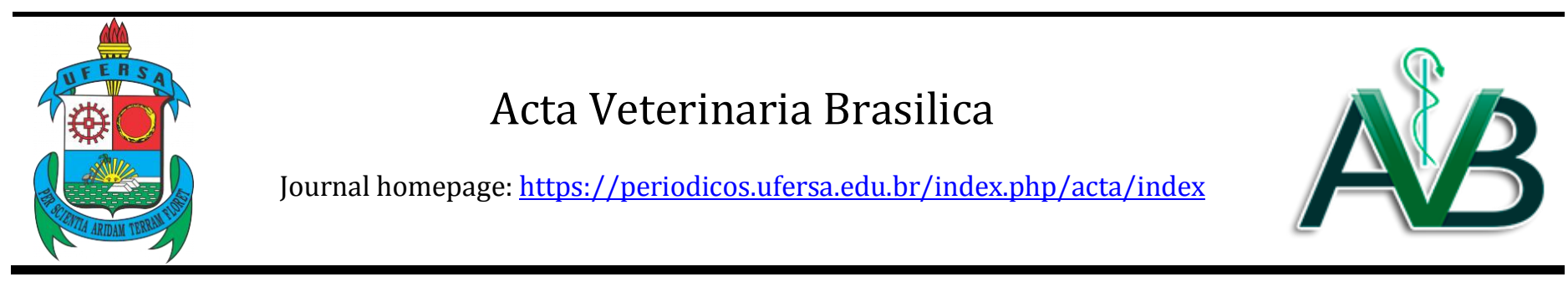

Original Article

\title{
Effect of gallium arsenide low-level laser therapy on the inflammatory phase of skin wound healing in rats
}

\author{
Armando de Mattos Carvalho1*, Michele Henrique Antônio Bizo², Hugo Shisei Toma², Karla Moraes Rocha \\ Guedes $^{3}$, Lívia Saab Muraro², Carlo Ralph de Musis ${ }^{2}$ \\ ${ }^{1}$ Departamento de Clínica e Cirurgia Veterinárias, Escola de Veterinária, Universidade federal de Minas Gerais (UFMG), Belo Horizonte, \\ MG, Brasil. \\ 2 Universidade de Cuiabá (UNIC), Cuiabá, MT, Brasil. \\ ${ }^{3}$ Empresa Brasileira de Pesquisa Agropecuária (EMBRAPA), Corumbá, MS, Brasil.
}

\section{A R T I C L E I N F O}

\section{Article history}

Received 23 August 2017

Received in revised form 05 October 2017

Accepted 10 October 2017

\section{Keywords:}

Photobiomodulation therapy

Thermography

Inflammation

Histopathology

\begin{abstract}
A B S T R A C T
The use of photobiomodulation therapy (PBMT) has shown promising results for the inflammatory modulation of tissue repair. This study aimed to evaluate the antiinflammatory potential of gallium arsenide (GaAs) PBMT in skin wound healing via (1) measurement of the temperature on the surface of the skin wound; (2) white blood cell count; and (3) histopathological examination. Skin lesions were induced on the dorsum of 20 Wistar rats, after which the animals were divided into two groups: a treatment group, subjected to GaAs PBMT, and a control group. Thermography was performed daily in all of the study animals until the end of the experiment. On the fourth day after lesion induction, whole blood was collected (white blood cell count), animals were euthanized, and skin lesions were biopsied (histopathological examination). There were no differences in the number of leukocytes and in the histopathological evaluations between the groups; however, the thermography analysis indicated an increase in temperature in the treated group. The antiinflammatory activity of GaAs PBMT was not confirmed. The increase in temperature on the surface of the skin lesions after LLLT requires further elucidation because this result could not be justified by the direct action of PBMT.
\end{abstract}

\section{INTRODUCTION}

The use of lasers in skin wound therapy has rapidly evolved in medicine. The low cost of the equipment combined with promising results has generated great interest among researchers in using this technique for the modulation of tissue repair. Promising results have been observed with the use of photobiomodulation therapy (PBMT) in skin wound healing, including decreased inflammatory activity (DE ARAÚJO et al., 2007), modulation of inflammatory mediators (FIORIO et al., 2017), neovascularization (LORETI et al., 2015; NOVAES et al., 2014) and faster tissue repair (REDDY; STEHNO-BITTEL; ENWEMEKA, 2001; NOVAES et al., 2014).
Tissue repair is divided into three distinct phases: inflammation, proliferation, and remodeling (BROUGHTON; JANIS; ATTINGER, 2006). However, this process is physiologically dynamic, with interactions and overlaps between the various stages of wound healing. The inflammatory phase begins immediately after injury via chemotaxis of inflammatory cells promoted by chemical mediators, such as histamine, prostaglandins, leukotrienes, interleukins, and nitric oxide (BALBINO; PEREIRA; CURI, 2005). Neutrophils are initially recruited to the wound site and are responsible for the debridement of devitalized tissue and bacterial destruction (BROUGHTON; JANIS; ATTINGER, 2006). Macrophages migrate to the wound site 48 hours after injury and are involved in both the completion of

\footnotetext{
${ }^{*}$ Corresponding author: armandodvm@gmail.com
} 
debridement and the secretion of cytokines and growth factors that promote angiogenesis, fibroplasia, and extracellular matrix (ECM) synthesis (GARZOTTO, 2009).

Thermography is an imaging method used to measure the heat emitted by surfaces and has several applications in medicine. It is easy to operate and non-invasive, and the equipment and maintenance are relatively inexpensive. Considering that inflamed tissues undergo increases in temperature, thermography has been used for the detection of tissue inflammation (CHRISTESEN et al., 2012).

Light amplification by stimulated emission of radiation (LASER) is characterized by a monochromatic, intense, coherent, and collimated light source whose radiation is emitted by external field stimulation (BUSNARDO; BONDO-SIMÕES, 2010; LORETI et al., 2015). PBMT may be developed with helium-neon ( $\mathrm{HeNe}$ ) or gallium arsenide (GaAs) lasers; it can modulate inflammation in several tissues and has the advantages of being noninvasive and non-pharmacological and producing few side effects (MEDEIROS et al., 2010). The antiinflammatory action of PBMT in the early stages of tissue repair is associated with the decrease in the number of inflammatory cells (MEDRADO et al., 2008; VILELA et al., 2012). However, some studies did not find any difference in the number of polymorphonuclear cells between the group treated with PBMT and the control group and consequently did not corroborate this anti-inflammatory activity (VIEGAS et al., 2007).

Therefore, there is no consensus on the antiinflammatory potential of PBMT in skin wound healing.
The conflicting data from different studies and the limitations of the evaluation parameters used in experimental designs raise doubts about the effects of laser therapy on wound inflammation. On the basis of these considerations, the present study aimed to evaluate inflammation in skin wounds in rats after the use of GaAs PBMT via infrared thermography and the numbers of inflammatory cells in the wound site (via histopathological examination) and in whole blood (via white blood cell count).

\section{MATERIAL AND METHODS}

All experimental procedures were submitted and approved by the Ethical Committee of Animal Use (Universidade de Cuiabá, 017/2014). Twenty male Wistar rats aged 12 months, weighing 318-469 g (average of $379 \mathrm{~g}$ ) were used. All animals were acclimated for seven days in individual cages, kept at $25^{\circ} \mathrm{C}$, and fed with a commercial feed (Presence $\AA$ Ratos e Camundongos) and water ad libitum.

The experimental design was based on the formation of two random groups: a treated group (TG), for whom the skin lesions were treated with laser therapy $(N=10)$, and a control group (CG), for whom the lesions were treated with a deactivated laser $(\mathrm{N}=10)$. As show in figure 1 , the experiment was initiated with the induction of skin lesions (day 1), followed by daily thermographic imaging of the skin lesions before and after laser therapy until the end of the experiment (day 4), when cardiac puncture was performed to collect blood for hematological evaluation and to biopsy the skin lesions for histopathological examinations.

Figure 1 - Experimental design.

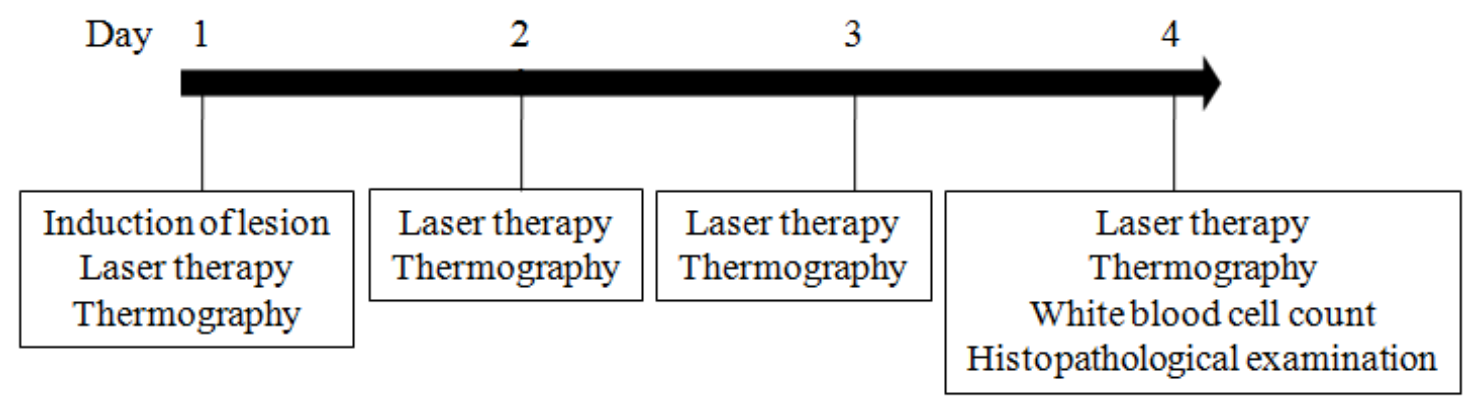

Source: author's collection.

Intramuscular anesthesia $(0.1 \mathrm{ml} / 100 \mathrm{~g}$ body weight was performed with $50 \mathrm{mg}$ of ketamine and $20 \mathrm{mg}$ of $2 \%$ xylazine, followed by a local anesthetic block via subcutaneous administration of $150 \mu \mathrm{L}$ of $2 \%$ lidocaine without vasoconstrictor on the site to be dissected. Then, the dorsal region between the chest and the neck of each animal was shaved. Before the surgical procedure, antisepsis was performed with a $10 \%$ de-germing solution of povidone-iodine, followed by $0.1 \%$ iodinealcohol. A sterile 6-mm skin punch (Kolplast ci Ltd.,
Itupeva, SP, Brazil) was used to remove a circular section of skin tissue.

After lesion induction, dressings were prepared daily with a $0.1 \%$ topical solution of povidone-iodine for all experimental animals.

The TG received a single daily application of GaAs PBMT on the wound site in an area equivalent to $3 \mathrm{~cm}^{2}$ on a regular time schedule. For this purpose, the animals 
were physically restrained using a 500-mL mineral water bottle that was manually adapted for that purpose, with a hole on the back that enabled the placement of dressings, performance of laser therapy, and thermal evaluation of the animals. GaAs PBMT was performed for 21 seconds at a wavelength of $904 \mathrm{~nm}$, peak power of 25 $\mathrm{W}$, pulse duration of $200 \mathrm{~ns}$, and energy density of 1 $\mathrm{J} / \mathrm{cm}^{2}$ (Physiolux Dual Vet Line, Bioset, Rio Claro, SP, Brazil). The CG was treated the same way as the TG, with the exception that the PBMT probe remained switched off and was positioned at the lesion site, with manual pressure on the skin lesion for 21 seconds, similar to the procedure used in the TG.

After adequate restraint of the animals, the skin lesions were macroscopically evaluated by daily acquisition of photographic images (camera model DSC-W510, Sony, China) to determine the presence of infection, hyperemic halo, crust formation, necrotic edges, and hemorrhage. In addition, infrared thermographic evaluation (FLIR, USA) was also conducted before and after PBMT by daily acquisition of images focused on the wound site at a distance of $25 \mathrm{~cm}$.

On the last day of the experiment, in addition to PBMT and macroscopic and thermographic evaluations, hematological evaluations and biopsies of the wound edges were performed. For this purpose, the animals were anesthetized $(0.2 \mathrm{ml} / 100 \mathrm{~g})$ with $50 \mathrm{mg}$ of ketamine hydrochloride combined with $20 \mathrm{mg}$ of $2 \%$ xylazine. After anesthesia, cardiac puncture was performed with a 3-ml syringe and a $22 \mathrm{G}$ needle for blood collection, and 2-ml samples were immediately transferred to test tubes containing $0.05 \mathrm{ml}$ of an aqueous solution of $10 \%$ disodium ethylenediamine tetraacetic acid (EDTA) for proper homogenization. All samples were transferred to the clinical laboratory of the Veterinary Hospital (Hospital Veterinário-HOVET), and a complete blood count was performed using a veterinary hematology analyzer (Sysmex poch-100iV ${ }^{\mathrm{T}}$, USA).
Immediately after blood collection, when the animals were still under the effects of dissociative anesthesia, a 5-mm skin biopsy was performed in the area between healthy and scar tissue. The samples were immediately stored in buffered $10 \%$ formalin solution. After skin biopsy, euthanasia was performed by intraperitoneal administration of sodium thiopental at a dose of 150 $\mathrm{mg} / \mathrm{kg}$.

Histopathological sections of the paraffin block were obtained and processed using the conventional deparaffinization method. The sections were stained with hematoxylin and eosin (HE) and were then examined under a light microscope by an experienced pathologist blind to the experimental groups of the slides. A semi-quantitative evaluation was performed considering the following morphological parameters: continuity of the epithelial surface, polymorphonuclear infiltration, neovascularization, and presence and morphology of fibroblasts. The results were classified according to the following scores: 0 - absent, 1 - mild, 2 - moderate, 3 - severe.

Data were statistically analyzed using the Kruskal-Wallis test. The mean \pm standard deviation was calculated for each parameter evaluated, and the CG and TG were compared.

\section{RESULTS}

Prior conditioning of the animals in individual cages for seven days and their physical restraint were essential for the proper performance of the experiments. The desensitization protocol and use of the skin punch for induction of the cutaneous lesion were effective. As show in figure 2, the use of PBMT and the macroscopic and thermographic evaluations were properly executed with the assistance of the container manually adapted for animal restraint.

Figure 2 - Physical restraint of the animals. (a) Application of gallium arsenide (GaAs) photobiomodulation therapy (PBMT). (b) Analysis of the wound area by infrared thermography before and after GaAs PBMT.

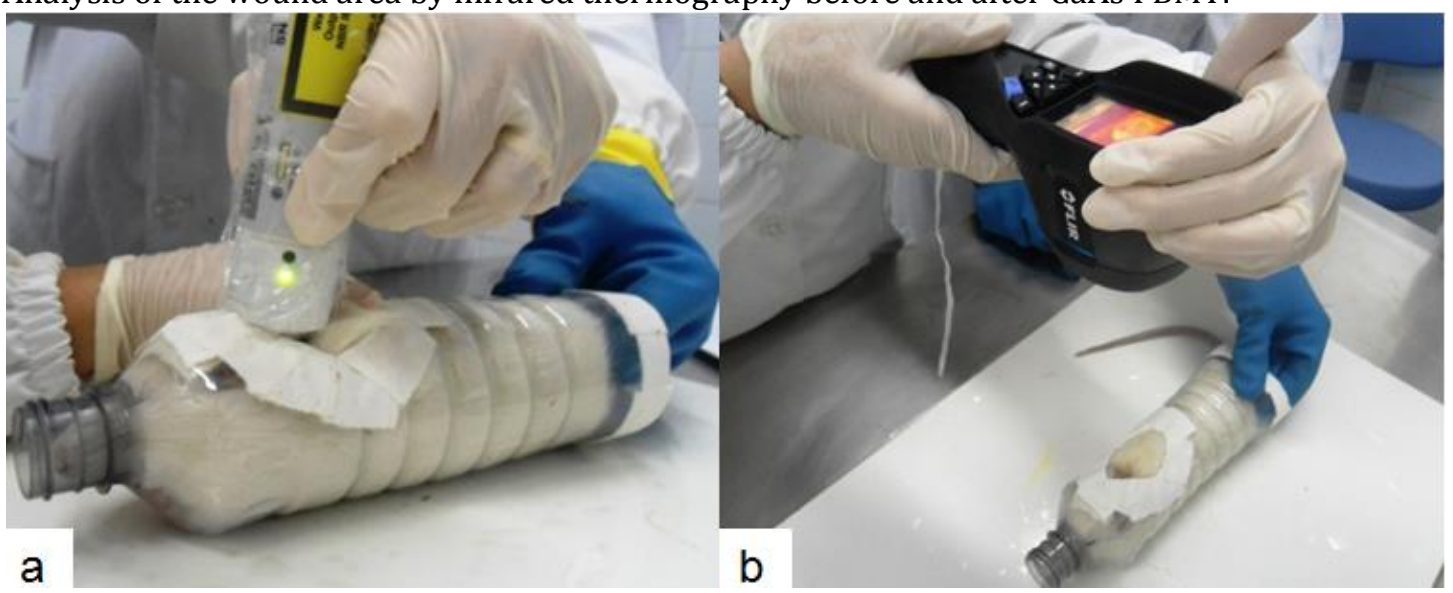

Source: author's collection. 
The numbers of leukocytes present in whole blood on the fourth day varied between 7600 and 12500 leukocytes/ $\mu \mathrm{L}$ (average of 10370 leucocytes $/ \mu \mathrm{L}$ ) in the CG and between 5600 and 117000 leukocytes/ $\mu \mathrm{L}$ (average of 9920 leukocytes $/ \mu \mathrm{L}$ ) in the TG; the difference between the groups was not significant. There was also no significant difference in the histopathological examinations between the two groups, as described in Table 1. However, as show in figure 3, there were significant differences between the groups for the thermographic evaluations (average temperature, with a $\mathrm{p} \leq 0.05$ ), with variations between $24.6^{\circ} \mathrm{C}$ and $35.9^{\circ} \mathrm{C}$ (average of $32.7^{\circ} \mathrm{C}$ ) in the $\mathrm{CG}$ and between $22.9^{\circ} \mathrm{C}$ and $37.8^{\circ} \mathrm{C}$ (average of $33.6^{\circ} \mathrm{C}$ ) in the $\mathrm{TG}$.

Table 1 - Average scores of the semi-quantitative histopathological evaluations in the control and treated groups.

\begin{tabular}{lcccc}
\hline & Continuity of the epithelial surface & Polymorphonuclear infiltration & Presence of fibroblasts & Neovascularization \\
\hline CG & 1.1 & 1.4 & 1.5 & 1.4 \\
TG & 0.9 & 1.2 & 1.1 & 1.4 \\
\hline
\end{tabular}

Scoring scheme used for semi-quantitative histopathological evaluation: 0 - absent, 1 - mild, 2 - moderate, 3 - severe. CG: control group; TG: treated group.

Figure 3 - Analysis of skin lesions by infrared thermography on the fourth day of the experiment. (a) Thermographic evaluation in the control group. (b) Thermographic evaluation in the treated group.
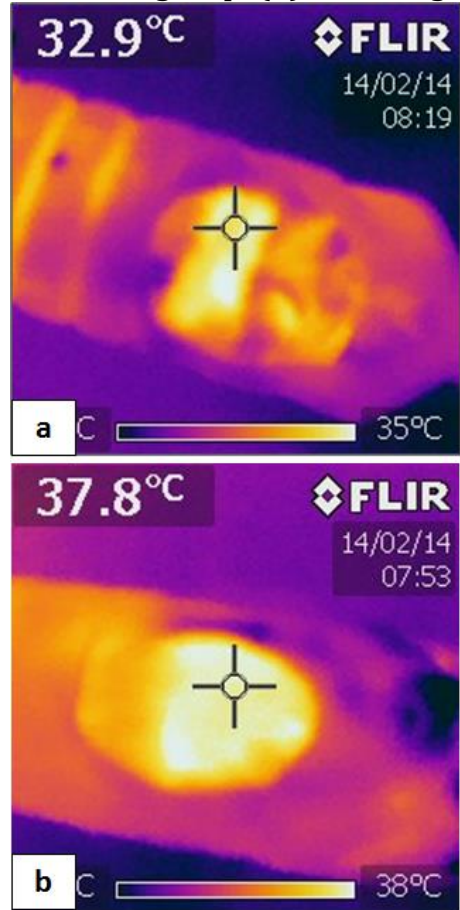

Source: author's collection.

\section{DISCUSSION}

The induction of skin lesions using a 6-mm skin punch was performed successfully in all animals and helped standardize lesions of similar sizes in the experimental animals, similarly to techniques reported in previous studies (KAWALEC et al., 2004; PEREIRA et al., 2010; FIORIO et al., 2017).

PBMT can modulate inflammation in various tissues. In addition, this technique is non-invasive, nonpharmacological, and has few side effects (MEDEIROS et al., 2010). There is still no consensus on the antiinflammatory activity of PBMT because previous studies have indicated a possible anti-inflammatory activity at the initial stages of the wound-healing process (MEDRADO et al., 2008; VILELA et al., 2012; PEREIRA et al., 2010), whereas other authors did not detect this activity (VIEGAS et al., 2007). There is also the report of the modulation of inflammatory mediators (FIORIO et al., 2017). Our results indicate that the absolute number of leukocytes and the score of the semi-quantitative histopathological evaluation (i.e., polymorphonuclear infiltration) were lower in the TG than in the CG; however, these differences were not significant and consequently did not confirm the anti-inflammatory activity of GaAs PBMT. A possible explanation for the failure to demonstrate this activity in the present study was the inadequate standardization of the GaAs PBMT technique used (PEREIRA et al., 2010; ALBERTINI et al., 2007). Although PBMT has been widely used in the past 30 years, some parameters, including the type of laser, the number and duration of applications, the period of treatment, and the type and source of light emission, need to be further elucidated for standardizing the 
methodologies and increasing the therapeutic efficacy (GONÇALVES et al., 2013; LORETI et al., 2015).

The infrared thermographic evaluation of skin lesions indicated a significant increase in temperature $(\mathrm{p} \leq 0.05)$ on the surface of the skin lesions in the group treated with PBMT. It is known that PBMT is characterized by the therapeutic application of lasers and superluminous monochromatic diodes with relatively low power $(<500$ $\mathrm{mW}$ ) for the treatment of diseases and injuries using doses that are too low $\left(<35 \mathrm{~J} / \mathrm{cm}^{2}\right)$ to produce detectable heat in the irradiated tissues (KITCHEN, 2006); therefore, tissue heating resulting from the direct action of laser therapy is unlikely. A possible explanation for the temperature increase in the skin lesions is the increased vasodilatation promoted by laser therapy (PEREIRA et al., 2010). However, blood flow evaluation was not performed in this experiment, which precludes this conclusion.

\section{CONCLUSION}

The anti-inflammatory activity of GaAs PBMT was not confirmed in the treatment of skin lesions in this study via hematological and histopathological examinations. However, a temperature increase on the surface of the skin wound was observed in the group treated with GaAs PBMT. To the best of our knowledge, no previous studies have used infrared thermography to measure the surface temperature of skin wounds in rats treated with laser therapy; therefore, this is a pioneering study on evaluating the temperature of skin lesions. However, the results obtained herein need to be further investigated, particularly with respect to the biological actions of PBMT that can potentially explain the increases in temperature on the surfaces of skin wounds.

\section{REFERENCES}

ALBERTINI, R.; VILLAVERDE, A. B.; AIMBIRE, F.; SALGADO, M. A.; BJORDAL, J. M.; ALVES, L. P.; MUNIN, E.; COSTA, M. S. Anti-inflammatory effects of low-level laser therapy (LLLT) with two different red wavelengths (660 $\mathrm{nm}$ and $684 \mathrm{~nm}$ ) in carrageenan-induced rat paw edema. Journal of photochemistry and photobiology, v. 89, n. 1, p. 50-55, 2007

BALBINO, C. A.; PEREIRA, L. M.; CURI, R. Mecanismos envolvidos na cicatrização: uma revisão. Revista Brasileira de Ciências Farmacêuticas, v. 41, p. 27-51, 2010.

BUSNARDO, V. L.; BIONDO-SIMÕES, M. L. P. Os efeitos do laser hélioneônio de baixa intensidade na cicatrização de lesões cutâneas induzidas em ratos. Brazilian Journal of Physical Therapy, v. 14, p. 45-51, 2010.

BROUGHTON, G. I.; JANIS, J. E.; ATTINGER, C. E. Wound Healing: An Overview. Plastic and Reconstructive Surgery, v. 117, n. 7S, p. 1e-S32e-S, 2006.

DE ARAÚJO, C. E. N.; RIBEIRO, M. S.; FAVARO, R.; ZEZELL, D. M.; ZORN, T. M. T. Ultrastructural and autoradiographical analysis show a faster skin repair in $\mathrm{He}-\mathrm{Ne}$ laser-treated wounds. Journal of Photochemistry and Photobiology B: Biology, v. 86, n. 2, p. 87-96, 2007.
FIORIO, F. B.; SANTOS, S. A.; RAMBO, C. S. M.; DALBOSCO, C. G.; SERRA, A. J.; MELO, B. L.; LEAL-JUNIOR, E. C. P.; CARVALHO, P. T. C. Photobiomodulation therapy action in wound healing repair skin induced in aged rats old: time course of biomarkers inflammatory and repair. Lasers in Medical Science, 2017. DOI: 10.1007/s10103-0172254-2.

GARZOTTO, C. K. Wound Management. In: HOPPER, D. C. S., ED. W.B. (Ed.). Small Animal Critical Care Medicine. Saunders: Saint Louis, 2009. cap. 157 , p. 676-682.

GONÇALVES, R. V.; SARANDY, M. M.; DA MATTA, S. L. P.; NOVAES, R. D.; PINTO, M. V. D. M. Comparative study of the effects of laser photobiomodulation and extract of Brassica oleracea on skin wounds in wistar rats: A histomorphometric study. Pathology - Research and Practice, v. 209, n. 10, p. 648-653, 2013.

KAWALEC, J. S.; HETHERINGTON, V. J.; PFENNIGWERTH, T. C.; DOCKERY, D. S.; DOLCE, M. Effect of a diode laser on wound healing by using diabetic and nondiabetic mice. The Journal of Foot and Ankle Surgery, v. 43, n. 4, p. 214-220, 2004.

KITCHEN, S. Eletroterapia - Prática Baseada em Evidências. 11. ed. Manole: Brasil, 2006.

LORETI, E. H.; PASCOAL, V. L. W.; NOGUEIRA, B. V.; SILVA, I. V.; PEDROSA, D. F. Use of laser therapy in the healing process: a literature review. Photomedicine and Laser Surgery, v. 33, n. 2, p. 104-116, 2015 .

MEDEIROS, J. L.; NICOLAU, R. A.; NICOLA, E. M.; DOS SANTOS, J. N.; PINHEIRO, A. L. Healing of surgical wounds made with lambda970-nm diode laser associated or not with laser phototherapy (lambda655 nm) or polarized light (lambda400-2000 nm). Photomedicine and Laser Surgery, v. 28, n. 4, p. 489-496, 2010.

MEDRADO, A. P.; SOARES, A. P.; SANTOS, E. T.; REIS, S. R.; ANDRADE, Z. A. Influence of laser photobiomodulation upon connective tissue remodeling during wound healing. Journal of Photochemistry and Photobiology. B, Biology, v. 92, n. 3, p. 144-152, 2008.

NOVAES, R. D.; GONÇALVES, R. V.; CUPERTINO, M. C.; ARAÚJO, B. M.; REZENDE, R. M.; SANTOS, E. C.; LEITE, J. P. V.; MATTA, S. L. P. The energy density of laser light differentially modulates the skin morphological reorganization in a murine model of healing by secondary intention. international Journal of Experimental Pathology, v. 95, p. 138-146, 2014.

PEREIRA, M. C.; DE PINHO, C. B.; MEDRADO, A. R.; ANDRADE ZDE, A.; REIS, S. R. Influence of $670 \mathrm{~nm}$ low-level laser therapy on mast cells and vascular response of cutaneous injuries. Journal of Photochemistry and Photobiology. B, Biology, v. 98, n. 3, p. 188-192, 2010 .

REDDY, G. K.; STEHNO-BITTEL, L.; ENWEMEKA, C. S. Laser photostimulation accelerates wound healing in diabetic rats. Wound repair and regeneration : Official publication of the Wound Healing Society [and] the European Tissue Repair Society, v. 9, n. 3, p. 248-255, 2001.

VIEGAS, V. N.; ABREU, M. E.; VIEZZER, C.; MACHADO, D. C.; FILHO, M. S.; SILVA, D. N.; PAGNONCELLI, R. M. Effect of low-level laser therapy on inflammatory reactions during wound healing: comparison with meloxicam. Photomedicine and Laser Surgery, v. 25, n. 6, p. 467-473, 2007.

VILELA, D. D.; CHAMUSCA, F. V.; ANDRADE, J. C.; VALLVE, M. L.; GONZALEZ, A. C.; ANDRADE ZDE, A.; MEDRADO, A. R.; REIS, S. R. Influence of the HPA axis on the inflammatory response in cutaneous wounds with the use of 670-nm laser photobiomodulation. Journal of Photochemistry and Photobiology. B, Biology, v. 116, p. 114-120, 2012. 